\title{
The Inevitable Instability of American Corporate Governance
}

\section{Citation}

Mark J. Roe, The Inevitable Instability of American Corporate Governance (John M. Olin Center for Law, Economics and Business, Harvard Law School, Discussion Paper Series No. 493, 2004).

\section{Published Version}

doi:10.2139/ssrn.615561

\section{Permanent link}

http://nrs.harvard.edu/urn-3:HUL.InstRepos:12207445

\section{Terms of Use}

This article was downloaded from Harvard University's DASH repository, and is made available under the terms and conditions applicable to Other Posted Material, as set forth at http:// nrs.harvard.edu/urn-3:HUL.InstRepos:dash.current.terms-of-use\#LAA

\section{Share Your Story}

The Harvard community has made this article openly available.

Please share how this access benefits you. Submit a story.

Accessibility 


\title{
HARVARD
}

JOHN M. OLIN CENTER FOR LAW, ECONOMICS, AND BUSINESS

\author{
THE INEVITABLE INSTABILITY OF \\ AMERICAN CORPORATE GOVERNANCE
}

Mark J. Roe

Discussion Paper No. 493

$09 / 2004$

Harvard Law School

Cambridge, MA 02138

This paper can be downloaded without charge from:

The Harvard John M. Olin Discussion Paper Series: http://www.law.harvard.edu/programs/olin_center/

The Social Science Research Network Electronic Paper Collection:

http://papers.ssrn.com/abstract_id=\#\#\#\#\#\#

This paper is also a discussion paper of the

John M. Olin Center's Program on Corporate Governance 

JEL Classifications: K4, H73, G34, G28

\title{
The Inevitable Instability of American Corporate Governance
}

\author{
Mark J. Roe
}

\begin{abstract}
American corporate governance faces two core instabilities. The first is the separation of ownership from control-distant and diffuse stockholders own, while concentrated management controls-a separation that creates not only great efficiencies but also big recurring breakdowns. In every decade since World War II, we've faced a fundamental large firm problem. Each emanated from this fundamental instability. We will not stabilize, once-and-for-all, this instability because some form of separation is necessary for large firms, because it provides large efficiencies, and because once we resolve one derivative problem, another will in time arise. The Enron-type scandals are just the latest manifestation of the core fissure in the large American public firm.
\end{abstract}

The second instability arises from our decentralized and porous regulatory system. Decentralization has key advantages—such as flexibility, specialization, and multiple informational channels - but with the advantages come costs in porosity. Our decentralized regulatory system leaves each regulator with weaknesses. Most importantly, they are not fully independent from the regulated. The regulated entities often deter the incompletely independent regulated from acting. The regulated can induce political authorities to deny the regulator enough power to act, they can get Congress to cut the regulator's funding, they can fight the potential regulations in courts and Congress, and they can weaken the quality of the regulation that they face. The Enron-class scandals illustrate this regulatory instability of American corporate governance well. Thus one structural response to the first fissure-separation and managers without immediate bosses-would be to facilitate gatekeeping, via strong boards that check managers, via strong shareholders with the motivation to channel managers toward profitability, via powerfully independent, professionally-driven accountants who verify managers' "report card," and so on. Some of these gatekeeping functions arise from contract, best practice, and the natural path of the market. Many are facilitated by regulation, but here the regulated-often managers themselves-can affect the regulatory outcomes, often weakening it. Some regulation that does occur arises when public outrage is sufficiently high that the regulation is more brittle and less supple than would be ideal.

Neither of these instabilities can be solved once-and-for-all, so that we can put it behind us. Instead, we resolve the local and immediate problem, move on, and in time face a new problem emanating from one or both of these core instabilities. We muddle through; we don't solve, because we can't.

* Professor, Harvard Law School. This paper will appear as a chapter in Restoring Trust in American Business, forthcoming from MIT Press in 2005. Thanks go to Jeffrey Gordon, Howell Jackson, Guhan Subramanian, and Andy Zelleke for comments on an earlier draft. 



\title{
THE INEVITABLE INSTABILITY OF AMERICAN CORPORATE GOVERNANCE
}

\author{
Mark J. Roe
}

Table of Contents

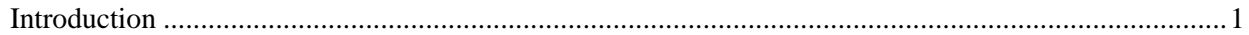

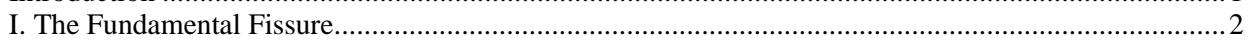

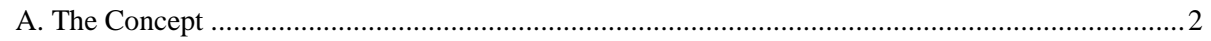

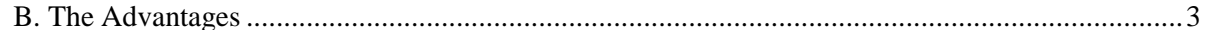

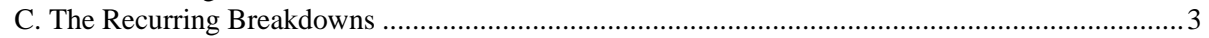

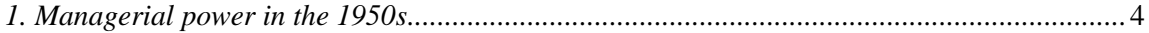

2. Expansion, satisicing, and maximizing sales in the $1960 \mathrm{~s}$ and $1970 \mathrm{~s} \mathrm{....................................} 5$

3. The conglomerates in the 1960s and 1970s......................................................................... 5

4. Hostile takeovers and competitive failure in the 1970s and 1980s............................................ 5

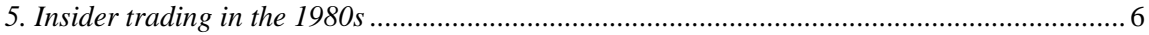

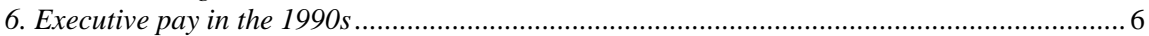

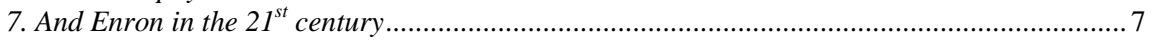

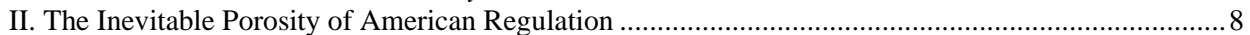

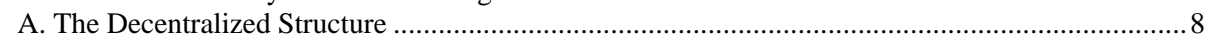

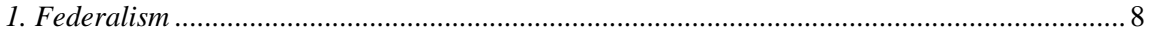

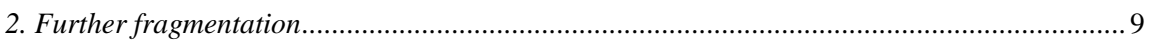

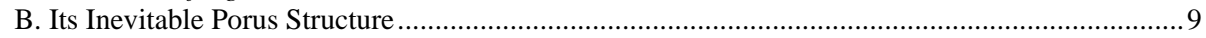

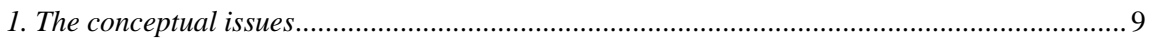

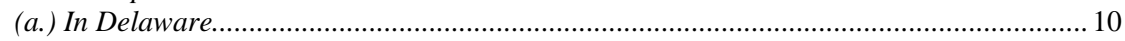

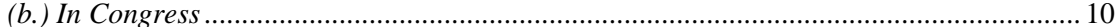

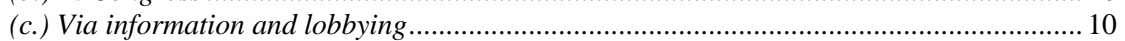

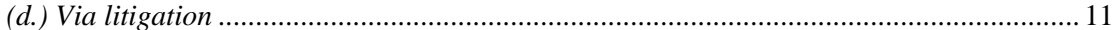

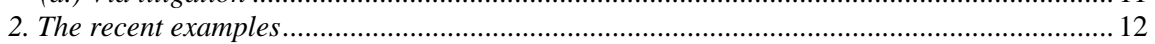

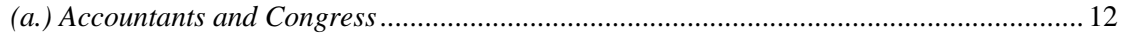

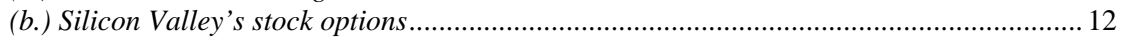

(c.) Cutting funding for the SEC; slowing the reforming after Enron .................................... 13

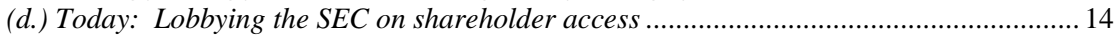

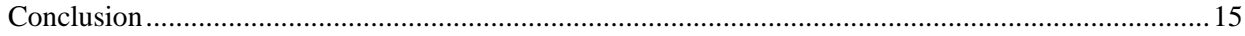





\title{
The Inevitable Instability of American Corporate Governance
}

\author{
(C) 2004. Mark J. Roe. All rights reserved.
}

\section{INTRODUCTION}

The recent business crises seem new and different from what has gone on before. But at their core, they are not. The core fissure in American corporate governance is the separation of ownership from control-distant and diffuse stockholders, with concentrated management-a separation that creates both great efficiencies and recurring breakdowns. True, some of the Enron-class scandals' specific problems are new, or exaggerated forms of what's come before-special purpose vehicles with complex funding arrangements, unusually high executive compensation with stock options a dominating component, failure at a venerable accounting firm, some inattentive boards of directors-but the specifics still derive from the core structure of American corporate governance. We will solve the current issues-or, more plausibly, reduce them to manageable proportions-but then sometime later, somewhere else, another piece of the corporate apparatus will fail. We'll have another corporate governance crisis and it will emanate from the same basic source: that ownership has separated from control in large firms. We'll patch it up, we'll move on, we'll muddle through. That's what will happen this time, and that's what will happen next time.

Separation is the foundational instability of American corporate governance. But it's not the only key instability, and the current crises exemplify the other key one as well. We have a decentralized and porous regulatory system. Yes, decentralization has key advantages: regulatory specialization, multiple channels of information flowing into the regulators, and the potential for multiple regulatory players to loosely check one another, without an overarching, potentially rigid regulatory monolith. One regulator might miss the problem, but—we hope—another one catches it.

But decentralization's advantages come with two costs in porosity. And they're big ones. First off, a corporate crisis could arise in which no specialized regulator is immediately equipped to head off the problem; and each may think the task really belongs to another regulator, thought to be better equipped to handle the current problem.

Moreover, and probably more importantly, our decentralized regulatory system leaves each regulator with weaknesses; each has incomplete authority. And the regulated can, and often do, exploit these weaknesses, sometimes deterring the regulator from acting well, either by influencing political authorities to deny the regulator authority, or by fighting the potential regulations in courts and Congress. This porosity deters much over-regulation, an important advantage here. But it also can deter good regulation. The Enron-class scandals illustrate well this instability of American corporate governance: gatekeepers like accountants kept their regulatory climate weak and fought back regulatory attempts to reduce their conflicts of interest. The presumably regulated firms influenced the accounting measures of profitability, most famously in whether stock options paid to executives and employees should be 
expensed just like other employee pay. And in reaction to the corporate governance crises, the Securities and Exchange Commission is now considering tilting boardroom authority a little less strongly toward managers-although by no more than a few degrees - but in trying to do so, they've faced a buzz-saw of managerial opposition, opposition that has thus far stopped the SEC from recalibrating shareholder-managerial authority.

Combine these two instabilities and we can see a deeper structure to the Enronclass breakdowns. To mitigate the problems of separation, markets and regulators have built institutions whose primary task is to check and validate managers' actions, since the separation of ownership from control raises the risk of managerial misdeeds. Some of that checking - "gatekeeping," in corporate governance parlance-is itself regulated. But with our porous system of regulation, the core regulated group-the managers - can induce regulators to weaken the direct oversight that they face, can influence Congress to deny the regulators enough funding to be effective, can deter good regulation, and can thereby render some gatekeepers ineffectual in checking managers. There's more than a little of that combination-a one-two punch to the belly of American corporate governance-in the Enron group of scandals.

\section{THE FUNDAMENTAL FISSURE}

\section{A. The Concept}

By the end of the $19^{\text {th }}$ century, the engineering advances in a continent-wide economy made large-scale production efficient. With the railroads running across the nation, production could be huge and local, but distribution could be national. ${ }^{1}$ The capital needed for that kind of production outstripped the capacity of even the wealthiest. To pool capital—especially in the cases of mergers and founders selling off their holdings-equity moved from controlling shareholders into dispersed stock markets, and ownership separated from control. The quintessential academic analysis came in Berle and Means' famous book. ${ }^{2}$ The nature of separation and its degree got an extra push from American populist politics, which kept American financial institutions-banks and insurers at the turn of the $20^{\text {th }}$ century-small, weak, and generally without authority to own stock. Had the banks and insurers been large and capable of owning stock, they could have played a larger role inside the large firm, as they did in other nations and as their successors are increasingly playing now-as institutional investors-in the early $21^{\text {st }}$ century. ${ }^{3}$

\footnotetext{
${ }^{1}$ Alfred D. Chandler, The Visible Hand: The Managerial Revolution in American Business (Cambridge: Belknap Press, 1977).

${ }^{2}$ Adolf A. Berle, Jr. and Gardiner C. Means, The Modern Corporation and Private Property (New York: Macmillan, 1933).

${ }^{3}$ Mark J. Roe, Strong Managers, Weak Owners: The Political Roots of American Corporate Governance (Princeton: Princeton University Press, 1994). And then we would have faced a different sort of separation, one that would have focused more on financial institutions - and hence on the separation between savers and the institution's portfolio-and less on corporate ownership.
} 


\section{B. The Advantages}

The advantages of separation are clear and need little repeating. Separation allows for a scale of operation far beyond any individual's capacity to provide capital. Even Bill Gates, the richest American, owns only 10\% of Microsoft. Distant outsiders, and a few other insiders, own the rest. Moreover, separation allows firms to combine managers with talent but without much capital (at least initially) with investors who have capital but neither the time nor the skills to manage. It provides founders a key exit strategy; exit barriers are also entry barriers, and if founders didn't have a range of exits, entrepreneurial activity would presumably be weaker than it is in the United States. Separation also allows investors to diversify, facilitating more efficient savings over time. And it facilitates product market competition, by easing the financing needs of start-ups and new entrants.

\section{The Recurring Breakdowns}

But separation's advantages come with costs. The most significant cost that repeatedly destabilizes corporate governance is that with ownership separated from management, managers' control of the firm can lead to poor results. No one might check them. Managers' goals sometimes deteriorate into just wanting to be paid well, to live well, and to keep those operations going that they understand, instead of doing the hard work of innovating for the firm, its stockholders, and American consumers. Without anyone checking, the problems might fester. More importantly, technologies and markets change, and sometimes the incumbent managers aren't the right ones to handle the change. But with ownership separated from control, they hang on for longer than is good for the economy.

Concentrated shareholding reduces separation's problems but comes with its own costs, mostly by enhancing the risk that insiders shift value from outside shareholders to themselves. Other nations face this problem more than we do. There's no "silver bullet."

We can see a series of American corporate crises in the half-century or so since World War II, all emanating from the core difficulty of separation. Our Enron and WorldCom crises are just the latest manifestation of the underlying fissure, the inevitable cost that comes with the benefits of separation. In the 1950s, the crisis was in the corporation's - and its managers'-overwhelming power in society, power that came when separation combined with domestic oligopoly that didn't yet face strong international competitors. In the 1960s, it was the large corporations' impulse to expand sales without regard to profits, innovation, or consumer well-being, often resulting in unwieldy conglomerates. Hostile takeovers burst on the scene in the late 1970s, and had become by the 1980s a cause célèbre of corporate, political, and social debate. In their best manifestation, they were the means to reduce the costs of separation, and make managers more responsive to markets. In their worst interpretation, they were the means by which greedy managers expanded their corporate empires. And by the end of the 1980s the insider trading scandals — centering on Ivan Boesky, Michael Milken, and a few others - were seen in the press, and 
perhaps by the public, as central to a tawdry corporate system. In the late 1990s, executive compensation - exemplified by CEO Michael Eisner's infamously large 1999 paycheck from Disney-seemed out of control. And then in the $21^{\text {st }}$ century's first decade we've had Enron, WorldCom, and associated failures, in which managers misstated their numbers, and their accountant watchdogs' eyes were closed. Or worse.

Each decade had its crisis, and each crisis had its quintessential academic analysts. And each crisis, and the analytic movement it precipitated, can be traced back to the separation of ownership from control, occasionally via a reaction, or overreaction, to the prior crisis. Let's review each breakdown in more detail.

1. Managerial power in the 1950s. The issue in the 1950s was power. Consider a primary academic document of that time, Edward Mason's edited collection of essays, The Corporation in Modern Society. ${ }^{4}$ (Mason was an economics professor at Harvard who had brought together a group of corporate thinkers to contemplate the 1950s firm.) The consensus view then was that the large corporation was a powerful creature that had to be tamed. Otherwise it would trample its employees, its customers, and its communities. It was too powerful, and the polity had to watch it warily. Public policy should be, it was thought, directed to taming and caging the firm.

Mason himself said: "This powerful corporate machine, which so successfully grinds out the goods we want, seems to be running without any discernible controls." Others said that the corporation had "produced a tension of power ... [as] giant enterprises ... come to rival the sovereignty of the state itself.", ${ }^{\circ}$ Looking back, I'd say that oligopolistic slack in the product markets had combined with ownership separation to give managers at the large firms - GM, GE, IBM-enormous power and discretion.

That power arose from the large American firms' command over capital, from their size, and from their insulation from strong competition in American oligopolistic markets that lacked serious international competition. Separation gave them discretion, and separation gave them freedom to build over-sized firms. The Big Three automakers, Big Steel, and the electrical equipment manufacturers were powerful firms with powerful managers who enjoyed discretion over what to do with abovenormal profits. Managerial discretion-from separation-and big profits made the power of American managers salient in 1950s. Would the powerful captains of industry distribute those supra-normal profits to themselves - via high salaries, nice offices, and a quiet life? Or to shareholders, to employees, to charity, or to customers via a better product?

That sense of overweening power faded. Antitrust policy was the central remedy in academic analyses in the 1950s and early 1960s. Perhaps merger policythe Justice Department and court decisions barred most big horizontal and vertical mergers during the era-made a difference, and academic analysts of the time hoped it would. But the rise of international competitors in manufacturing also affected

${ }^{4}$ Edward Mason, ed., The Corporation in Modern Society (Cambridge: Harvard University Press, 1959). More detail on this era can be found in Mark J. Roe, "From Antitrust to Corporate Governance? The Corporation and the Law: 1959-1994,” in Carl Kaysen, ed., The American Corporation Today (Oxford: Oxford University Press, 1996), 102-127.

${ }^{5}$ Mason, ed., The Corporation in Modern Society, 3-4.

${ }^{6}$ Id., 218. 
American managerial power, perhaps more so. Heightened competition and rapidly changing technologies changed managers from the all-powerful players the academics found them to be in the 1950s, to misdirected builders of unwieldy conglomerates by the 1970s, and then to failures at reconstructing their firms in the 1980s.

But at the core of the perceived problem of the 1950s was ownership separation. Separation and strong profits gave those firms' managers discretion over an enormous pool of profits and capital that far exceeded the individual wealth of any of them. They could build and run big, over-sized firms. They seemed powerful, and they were.

2. Expanding, satisficing, and maximizing sales in the 1960s and 1970s. By the late 1960s and early 1970s, the perception changed from power to waste. Firms spent too much on advertising, provided too many quickly-obsolete products, and expanded for size, not profits. Managerialism was still front and center, but the dominant sense then-reflected in Oliver Williamson's classics—was that managers maximized their power, prestige, and salaries by maximizing sales. As to profits, they merely satisficed. Managers couldn't ignore profits entirely, but as long as they were in an acceptable range, it was sales that they sought to maximize. ${ }^{7}$

3. The conglomerates in the 1960s and 1970s. Bloat and discretion had their quintessential corporate form: the American conglomerate of that era. A headquarters of strategic thinkers would direct the far-flung subsidiaries in the multi-divisional corporation. Local managers would have local information and skills, while the central managers had vision and the capacity to allocate capital. For a time the conglomerate was not seen as a problem, but as a solution to ownership separation, as the central managers at headquarters would monitor the operating managers in the divisions and subsidiaries, giving the stars more capital and squeezing money out of the weaker divisions. This state of affairs - and the conglomerates' capacity to reduce separation's managerial problems—was briefly celebrated in economics circles. ${ }^{8}$

4. Hostile takeovers and competitive failure in the 1970s and 1980s. By the 1980s, the large American manufacturing firm looked like it was on the ropes. Powerful European and Japanese competitors were out-producing their American rivals. Oligopolistic profits were gone, as the big firms in industry after industry had to compete with tough players from overseas. Something had to be done to squeeze out corporate bloat, to make the American firm lean, mean, and competitive once again, to dismantle the slow-moving conglomerates. Conglomerates were no longer the solution to the separation fissure, they were its biggest problem.

The market and theory also gave us a mechanism to reduce separation's thencurrent critical problem - the conglomerate and the misdirected manager-via the hostile takeover. The takeover entrepreneur would buy up the firm's stock, sell off the divisions separately, and then make a profit because the pieces could be better

${ }^{7}$ Oliver E. Williamson, The Economics of Discretionary Behavior: Managerial Objectives in a Theory of the Firm (Englewood Cliffs, N.J.: Prentice Hall, 1964). See also Robin Marris, The Economic Theory of "Managerial" Capitalism (London: Macmillan, 1964); Herbert A. Simon, "Theories of Bounded Rationality," in C. B. McGuire and Roy Radner, eds., Decision and Organization (Amsterdam: North Holland, 1972); Richard M. Cyert and James G. March, A Behavioral Theory of the Firm (Princeton: Prentice Hall, 1962).

${ }^{8}$ Oliver E. Williamson, Markets and Hierarchies: Analysis and Antitrust Implications: A Study in the Economics of Internal Organization (New York: Free Press, 1975). 
managed separately than jointly in the slack-heavy conglomerate; so buyers would pay more for the better-managed separate divisions, enough to cover the costs of the takeover. This possibility was celebrated in financial analyses, most prominently by Michael Jensen. ${ }^{9}$ Leveraged buyouts would focus managers' attention on a single firm with a single product, reducing separation's problems.

Counter-arguments arose. Firms needed to make commitments to their employees, and a deep hostile takeover market made managerial commitments worthless, because the managers could be thrown out. In the public arena, a key issue was seen to be that takeovers broke implicit promises that managers made to employees, who thought they had an understanding that they would keep their jobs as long as they did their work well, not just for as long as markets-financial, product, and takeover-agreed. And some takeovers were done not to dismantle the bloated conglomerate, but to build more power for the offering managers. But wherever one stood on these issues, the source of the problem was clear: it was again the separation of ownership from control.

5. Insider trading in the 1980s. Separation meant those trading stock would often have less information than those inside the corporation. Often that disparity of information wasn't very important, because the insiders didn't know much that would change the value of the stock. Though cases of unlawful insider trading arose intermittently and others presumably went undetected, the problem seemed decidedly second-order.

The explosion of takeovers changed that. Players who got wind of a takeover at a big premium had information that they could trade on profitably. They could buy stock from naïve, distant individual investors at low prices, and then make a bundle when the offer was announced. Not only did inside managers have this information, but so did inside Wall Street professionals - and the Wall Streeters knew how to trade fast and well. The burst of inside trading led to headlines, indictments - most famously of Michael Milken, the junk bond trader, and Ivan Boesky, the arbitrageur-and demeaned the legitimacy of the stock market in the eyes of many. ${ }^{10}$

6. Executive pay in the 1990s. In 1999, Michael Eisner's pay was more than $\$ 500$ million, including profits from the stock options he cashed in. ${ }^{11}$ Some thought that excessive, and his paycheck got headlines and media attention; others thought it a just reward for the shareholder value he initially created. ${ }^{12}$ Executive pay rose then both in absolute and relative terms. Executive pay was about 40 times the average

\footnotetext{
${ }^{9}$ Michael C. Jensen, “Agency Costs of Free Cash Flow, Corporate Finance, and Takeovers,” American Economic Review Papers \& Proceedings 76 (1986): 323.

10 Milken was not indicted for insider trading, but for securities violations arising from "parking” stock.

11 See "Forbes Executive Pay,” available at www.forbes.com/lists.

${ }^{12}$ See Elizabeth Smith, “This is Not Michael Eisner’s Pay Stub...,” Fortune (June 8, 1998): 294; "Who Wants to Be a Billionaire?," The Economist (May 8, 1999) (p. 14); "Who Earned the Pay-And Who Didn’t,” Business Week (April 19, 1999): 75. Some commentators thought that Disney's stock performance justified the pay; indeed, by tying compensation to performance, the high compensation may have caused the excellent financial results. The paycheck was still controversial.
} 
worker's pay from the 1950 s to $1980 .^{13}$ After a sustained rise in executive pay during the 1990s, CEO compensation rose from 140 times to 500 times the average employee's pay by 2003. ${ }^{14}$ Explanations are several. The pay could have been efficient, in better aligning senior managers with stockholders. ${ }^{15}$ The pay rewarded modern executives for the excess risks that managers faced in a volatile 1990s, when executive turnover was rapid. The CEO got paid well, but, like a star athlete, would only keep that job for a few years. 16

Or the pay resulted from ownership separation. No one was checking managers closely; norms had changed; and executives could now cash in on their power inside the firm. ${ }^{17}$

7. And Enron in the $21^{\text {st }}$ century. And then came Enron. Enron's managers, most notably Chief Financial Officer Andrew Fastow, misstated their firm's numbers, in ways that moved funds out from Enron and into their own pockets, and no one caught it. Enron's obligations via the related special purpose vehicle financings weren't stated in Enron's financials. The board's audit committee didn't catch the problem; the board suspended the firm's own conflict-of-interest rules; and the firm's accountants didn't react to the problem. Separation meant that those watching internally — the board and its committees - weren't watching their own money. With specialization they depended on others for information-primarily lower-ranking managers inside the firm, like Fastow, but also outsiders-and those others didn't provide it well. While Enron's fraud in using the related entities - the special purpose vehicles-was novel in its specifics, WorldCom's financial misstatements were more ordinary—just big.

So when ownership separates from control, problems arise. Managers pursue their own agenda, and it seems that in every decade there's been a systematic failure. Combine separation with oligopoly and we got enormous power in the 1950s. Combine separation with ideas about conglomerates and we got mega-firms without continued justification in the 1960s. We got solutions-like hostile takeovers-against which the public reacted in the 1980s. We got hyper-pay in the 1990s, which was partly a solution and partly a resultant problem. And in the beginning of the $21^{\mathrm{st}}$

13 "Face Value: Business as the New Rock and Roll," The Economist (November 28, 1998): 70; John A. Byrne, “What, Me Overpaid? CEOs Fight Back,” Business Week (May 4, 1992): 142143.

${ }^{14}$ Janice Ravel, "Mo’ Money, Fewer Problems: Is it a Good Idea to Get Rid of the \$1 Million CEO Pay Ceiling?” Fortune (March 31, 2003): 34.

${ }^{15}$ Brian J. Hall and Jeffrey B. Liebman, “Are CEOs Really Paid like Bureaucrats?” Quarterly Journal of Economics 63 (1998): 653; Kevin Murphy, "Executive Compensation,” in Orley Ashenfelter and David Card, eds., Handbook of Labor Economics (Amsterdam: North Holland, 1999).

${ }^{16}$ Rakesh Khurana, Searching for a Corporate Savior: The Irrational Quest for Charismatic CEOs (Princeton: Princeton University Press, 2002).

${ }^{17}$ Lucian A. Bebchuk and Jesse M. Fried, “Executive Compensation as an Agency Problem,” Journal of Economics Perspectives 17 (2003): 71-92; Lucian A. Bebchuk and Jesse M. Fried, Pay Without Performance: The Unfulfilled Promise of Executive Compensation (Cambridge: Harvard University Press, 2004, forthcoming); Michael C. Jensen and Kevin J. Murphy, "CEO IncentivesIt’s Not How Much You Pay, But How,” Harvard Business Review 68 (May-June 1990): 138-149. 
century we got misstated financial statements that undermined confidence in stock markets, and made the mis-staters (temporarily) rich.

We haven't been able to fully stabilize the collateral damage from ownership separation. Weaknesses appeared, became toxic, and then we had to cure and repair. But we would do better than we have thus far-or at least we would have a differing set of primary problems-were it not for the negative effects of the second major instability in American corporate governance: the porous nature of regulation. American regulation is open and decentralized, and those qualities give the regulated — often the very managers whom we are trying to direct toward efficiency and away from scurrilous behavior - the capacity to influence, and often weaken, that regulation.

\section{The Porosity of American Regulation}

\section{A. The Decentralized Structure}

1. Federalism. The United States doesn't have a centralized “czar” whose job it is to regulate corporate governance. Often this decentralization is celebrated, especially when it's in the form of state competition for corporate charters, and the concomitant regulation of the corporation via state corporate law. ${ }^{18}$ That state-based regulation tends to come through contractual enabling - the corporate charter can be built in almost any way that the participants prefer-and judge-enforced fiduciary duties. Regulatory commissions and criminal actions are largely absent in making state corporate law. ${ }^{19}$

That said, corporate governance is also federal, via the securities laws and the SEC. True, the SEC's power here is incomplete, mostly centered on disclosure and trading in the securities markets. But corporate governance can be deeply affected by simple disclosure. That is, most states have some rule or another against thievery and interested party transactions. The transactional problem is how to get that information out from inside the corporation. Mandatory disclosure rules, mandatory accounting rules, and SEC control (or influence) over the accounting profession can-when the SEC acts properly and is adequately funded-deeply affect corporate governance. ${ }^{20}$

${ }^{18}$ Roberta Romano, The Genius of American Corporate Law (Washington, D.C.: AEI Press, 1993). Not everyone is happy with this decentralization, with many analysts thinking it leads to rules that overly favor managers. William L. Cary, "Federalism and Corporate Law: Reflections upon Delaware,” Yale Law Journal 83 (1974): 663, 705; Lucian Arye Bebchuk, "Federalism and the Corporation: The Desirable Limits on State Competition in Corporate Law," Harvard Law Review 105 (1992): 1437, 1509.

${ }^{19}$ Cf. Mark J. Roe, “Delaware’s Advantage” (working paper, 2004).

${ }^{20}$ Mark J. Roe, “Delaware’s Competition,” Harvard Law Review 117 (2003): 588-646. Cf. William W. Bratton, “Corporate Law's Race to Nowhere in Particular,” University of Toronto Law Journal 44 (1994): 401, 419; John C. Coffee, Jr., "The Future of Corporate Federalism: State Competition and the New Trend Toward De Facto Federal Minimum Standards," Cardozo Law Review 8 (1987): 759, 768; Melvin Eisenberg, “The Structure of Corporation Law," Columbia Law Review 89 (1989): 1461, 1512; Arthur Fleischer, Jr., "Federal Corporation Law: An Assessment,” Harvard Law Review 78 (1965): 1146 (federal disclosure rules control fiduciary behavior); Mark J. 
2. Further fragmentation. And then there's Congress. It acts sporadically in corporate governance, but it does act. And courts sometimes interpret key provisions of the securities or other federal laws to make corporate policy. Moreover, some elements of corporate governance are self-regulatory: The New York Stock Exchange makes governance rules, though often after SEC prodding. And private codes of conduct arise from time to time.

This fragmented nature sometimes allows one regulator to check the other; if one state doesn't act, then maybe the New York Attorney General will swing into action. If states are in managers' palms, then maybe an SEC with overall American economic performance in mind will use its bully pulpit to induce action, or might act directly itself.

But the fragmented nature of regulation also allows some potential innovation and cross-checking to fall unused through the cracks. Stock exchange officials might consider forensic audits to be a good idea, but the stock exchanges could think it's someone else's job to push for it. Delaware's judges bemoan the fact that they can't do the fact-finding and prospective regulation that a regulatory agency could undertake. $^{21}$ That is, one of our most important corporate governance regulators can only act after the fact, when private parties bring it a case to decide. The SEC could bemoan its lack of full power over the public corporation; it might have lots of good ideas, but the securities laws give it only incomplete authority, and the Business Roundtable (and the business lobby more generally) stands ready to remind the SEC (and, if necessary, the federal courts) of the limits to the SEC's power.

\section{B. The Inevitably Porous Structure}

1. The conceptual issues. Fragmentation obviously has its advantages and its disadvantages. One can't say in the abstract which is better, fragmentation or centralization. On the plus side, we don't suffer from an unchecked, monolithic regulator. And we usually don't suffer from too much over-regulation. Differing regulators have differing sources of information, differing regulatory styles, and differing modes of enforcement. The regulated can interact with the regulators to bring to bear the information they have to make the resulting regulation better than it would otherwise be and to avoid a regulator's tendency to over-regulate. It's easy for a regulator to be too tough on boards of directors. The regulator gets credit for solving the problem, but then the boards become less attractive for directors to join, or less effective in running the nation's business. Pushback from the regulated reduces overregulation.

But decentralization, even if good on balance, is not good in all respects. Some items may fall through the cracks, and that might be the price we pay for the advantages of decentralization. But the regulated have a deep impact on the fragmented regulators and that raises the costs even higher.

Roe, “Takeover Politics,” in Margaret Blair, ed., The Deal Decade (Washington, D.C.: Brookings Institution Press, 1993), 321, 340-347.

${ }^{21}$ One wonders why they don't ask the Delaware legislature to set up a corporate law regulatory agency. 
(a) In Delaware. Everyone agrees that managers strongly influence the making of Delaware's corporate law. While the judiciary is independent, the legislature can, and sometimes does, overturn the courts. And the Delaware legislature acts after a bar association committee-drawn from leaders of the law firms that represent managers and sometimes investors-recommends action. The agreement on managerial influence is wide; the difference in opinion is on whether that influence is pernicious or, overall, beneficial. ${ }^{22}$ Perhaps managerial influence explains why, for better or worse, Delaware is not seen as a tough regulator, why it doesn't use criminal penalties for corporate governance misdeeds, and why it has no forward-looking powerful regulator.

More generally, consider how the states, and Delaware in particular, responded to takeovers in the 1980s. Conceptually takeovers can be seen as a key way to reduce the costs of ownership separation; mediocre managers would find their stock price dropping. Outsiders would buy up the stock, fire the managers, reconstruct the firm to be profitable, and thereby make the takeover pay for them. But target firm managers disliked takeovers. So they lobbied state legislatures to bar them, often successfully. Takeovers were one way to reduce the costs of separation, but the regulated affected how easily takeovers could occur. Most states passed laws that made hostile takeovers much harder, and managers' lobbying was central to getting those laws enacted. ${ }^{23}$ And while Delaware was slow to enact an anti-takeover law, it did come around, and managerial influence was quite visible.

(b) In Congress. Congress can regulate corporate governance. But its members run for election, and they need campaign contributions.

Takeovers again provide an example. In the 1980s, hostile takeovers were central to American corporate governance. In the late 1980s, Congress considered legislation that would have barred many of managers' defensive measures. Lobbying by the Business Roundtable — big firms' lobbying organization—probably affected the outcomes of what passed, or more accurately, didn't pass.

Moreover, Congress can control other regulators, like the SEC. Managers who face a loss with the SEC can lobby Congress to rein the SEC in.

(c) Via information and lobbying. The regulated can bring forward and highlight the negative aspects of any proposed regulation of themselves, or any looming empowerment of their gatekeeper-watchers. In the balance, the proposed regulation could then seem less wise than it otherwise would look.

${ }^{22}$ And, actually, some are less certain of how independent the judiciary always is. Judges are picked after vetting by bar associations and law firms, after their corporate loyalty is tested. See William L. Cary, “Federalism and Corporate Law: Reflections upon Delaware,” Yale Law Journal 83 (1974): 663; Jonathan R. Macey and Geoffrey P. Miller, "Toward an Interest-Group Theory of Delaware Corporate Law,” Texas Law Review 65 (1987): 469, 473.

${ }^{23}$ Roe, Strong Managers, 151-168; Roe, “Takeover Politics,” in Margaret Blair, 340-347; Joseph A. Grundfest, "Subordination of American Capital," Journal of Financial Economics 27 (1990): 89-114; Roberta Romano, “The Political Economy of Takeover Statutes," Virginia Law Review 73 (1987): 11. Some state legislators surely thought takeovers were bad policy. And others responded to target firm employees' interests, not just managerial interests. But no one would deny that managers were important lobbyists for state anti-takeover laws. 
In 1991, the SEC proposed loosening up the then-severe restrictions on institutional investor action, some of which continue today. At that time, if institutional investors talked widely enough about dysfunctional boards and how some board members should be turned out, they risked criminal prosecution for failing to file a proxy statement. (While the risk of real criminal prosecution was low, the real risk of some SEC enforcement action and its concomitant embarrassment was enough to deter activity.) The securities laws required a proxy filing when shareholders communicated with the intention, or as part of a plan, to change control of a corporation. When the SEC first brought forward its plan to loosen up the rigid rules here, managers spoke of smoke-filled back-room deals among institutional investors to the detriment of small stockholders. ${ }^{24}$ The SEC withdrew its proposed rule and, for a time, it seemed dead. Then the SEC came back with a weaker but still viable version, and promulgated that rule. $^{25}$

Another instance is the American Law Institute's effort to promulgate standards for corporate governance that would tighten up the structure of the American corporation at its top. The Institute is run neither solely by ivory tower professors nor by regulators fully separated from the regulated. Business lawyers-managers' representatives, corporate counsel, and so on-are big players, and they defeated several proposals to tighten up corporate governance. Reformers trying to draft the ALI Corporate Governance rules "were opposed by a cohesive group of corporate counsel and the companies who employed them. The ALI ultimately adopted a vague rule that permitted directors and state courts to do what they had previously been doing. ${ }^{26}$ We have a looser system—for good or ill—partly because it’s the managers' representatives who drafted, or had to approve, many of the rules and quasi-rules.

(d) Via litigation. The regulated can attack regulation that would better align managers and insiders with stockholders. One well-known example is the SEC's effort to reduce insider power by barring recapitalizations that led to insiders having more votes per share of stock than outsiders. Such recapitalizations were at the time a common method for target firm stockholders to resist hostile takeover offers; they kept enough votes for themselves to stop takeovers that other shareholders might have wanted. The Business Roundtable opposed the rule. When the SEC promulgated it

24 "Business Roundtable Criticizes SEC Plan on Shareholder Data," Wall Street Journal, September 20, 1991, A4.

${ }^{25}$ Stephen Labaton, “U.S. Pressed by Business Over S.E.C,” New York Times, October 18, 1991, D1: The Business Roundtable met with the administration to bypass the SEC "in trying to prevent new rules for corporate shareholder battles." The Roundtable also attacked the SEC's proposed rules as allowing back-room corporate deals. See also Roberta S. Karmel, "CalPERS versus the Business Roundtable,” New York Law Journal (February 21, 1991): 3.

${ }^{26}$ Alan Schwartz and Robert E. Scott, "The Political Economy of Private Legislatures," University of Pennsylvania Law Review 143 (1995): 595-642. Similarly, Stephen M. Bainbridge, "Independent Directors and the ALI Corporate Governance Project," George Washington Law Review 61 (1993): 1034, 1044, 1048, 1052. Bainbridge reports that it was alleged "that corporations were hiring members of the ALI to represent their interests in that body's deliberations and that they were removing their legal business from law firms with partners who were sympathetic to the ALI's pro-litigation outlook." See also Jonathan R. Macey, "The Transformation of the American Law Institute,” George Washington Law Review 61 (1993): 1212, 1228-1232. 
anyway, the Roundtable attacked the SEC's rule as exceeding the SEC's authority under the securities laws. They won. ${ }^{27}$

2. The recent examples. Both the run-up to the Enron scandals and the regulatory reaction display America's porosity in regulating corporate governance. Some of it is on the positive side: Congress reacted proactively via the SarbanesOxley Act of 2002, and Delaware has gotten tougher on insiders since the scandals broke. The New York Attorney General swung into action, and the SEC has begun to consider rules that would further regulate managers and accountants. Multiple regulations offered multiple solutions, emanating from their specialized strengths.

But not all porosity was good. Accountants as lobbyists with Congress had held off the SEC from reducing accountants' conflicts of interests. The regulated in general-managers as well as accountants—watched as an anti-regulatory Congress starved the SEC of funding. ${ }^{28}$ Managers at first slowed Sarbanes-Oxley reforms in Congress. One reformer-John Biggs-was blocked from taking over the regulation of the accounting gatekeepers. And managers and their regulatory allies have thus far stopped the SEC from tightening up corporate governance in a way that would heighten shareholder oversight.

Let's look at these in more detail.

(a) Accountants and Congress. Accountants were auditing their clients and selling them consulting services, often of tax strategy or in information systems. Managers could influence their gatekeepers by turning the consulting revenue spigots open, or by closing them. ${ }^{29}$ Arthur Levitt, the chair of the SEC, wanted to break this conflict. In June 2000, the SEC proposed rules to separate auditing from consulting.

But the accountants lobbied Congress to stop Levitt. They succeeded. ${ }^{30}$ Levitt's abortive effort here is instructive. Congress, in effect, told Levitt not to go forward, threatening both to cut SEC funding further and to reduce SEC authority. The SEC cannot resist a determined Congress. And this time at least, the gatekeepers got to Congress. Levitt watered down the new rules, and didn't separate auditing from consulting. $^{31}$

(b) Silicon Valley's stock options. Silicon Valley liked to pay employees in stock options. If the firm's stock soared, the employees got rich. But the firms didn't like to deduct the value of the stock option as a cost of operating their firm. The

\footnotetext{
${ }^{27}$ Business Roundtable v. SEC, 905 F.2d 406, 407 (D.C. Cir. 1990). The Roundtable at least won the battle. The SEC eventually induced the stock exchanges to promulgate one-share, one-vote rules.

${ }^{28}$ David E. Rovella, “Congressional Ploys Squeeze SEC Budget; A fight over the agency's budget creates fiscal crisis,” National Law Journal, September 5, 1994. Congress cut the SEC's funding request from \$305 million to \$125 million. And Congress also nixed the SEC's plea to fund itself with further user fees: "Sen. Phil Gramm, R-Texas, who led the Republican effort to scuttle self-funding, said SEC independence 'would only increase the likelihood of escalating fees on the securities markets' and make the agency less responsive to Congress.”

${ }^{29}$ Jeffrey N. Gordon, "What Enron Means for the Management and Control of the Modern Business Corporation: Some Initial Reflections," University of Chicago Law Review 69 (1992): 1233-1250.

${ }^{30}$ For a critical reportorial account, see Mike Brewster, Unaccountable: How the Accounting Profession Forfeited a Public Trust (New York: John Wiley \& Sons, 2003).

${ }^{31}$ Brewster, Unaccountable: How the Accounting Profession Forfeited a Public Trust.
} 
accountants' regulatory organization, the Financial Accounting Standards Board (usually known as FASB) decided that employee pay in cash and employee pay in stock options were each still pay that was an expense to the corporation. Expenses had to be deducted from income. They moved toward requiring the value of employee stock options to be deducted from a firm's accounting profits.

But FASB never required American firms to deduct the value of options given to employees. Why? The regulated-here, Silicon Valley, the prime users of stock options-got to the regulators, this time through Congress:

Following an intense lobbying campaign by Silicon Valley companies, several leading members of Congress, including Joseph Lieberman and Diane Feinstein, threatened to put the F.A.S.B. out of business if it went ahead with the change. The board backed down, [and thus that] ... official attempt to control corporate avarice came to an end. ${ }^{32}$

As Donald Langevoort points out in this volume, this ability of the regulated to influence the regulators further rationalized some managerial financial misreporting. ${ }^{33}$ Since the government backed down, why should executives try harder to report financial results precisely?

And despite the post-scandal backlash, it's not yet over: The Silicon Valley lobbyists are still at it, in 2004:

Silicon Valley was [in July 2004] sitting on ... members of Congress, whispering sweet nothings in their ears. As in, stock options cost nothing. And 312 members of the House listened.

That was the number of congressmen who voted for the Baker Bill, a measure that damages efforts of the Financial Accounting Standards Board to enact rules mandating the expensing of stock options. The bill violates FASB's independence....

Not able to fight stock-option expensing completely, Silicon Valley was content with a compromise. Knowing that something is wrong with not expensing any stock options, the writers of the Baker Bill want stock options for only the CEO and the next four highest-paid executives to be expensed. ${ }^{34}$

(c) Cutting funding for the SEC; slowing reform after Enron. In the 1990s, Congress sharply cut funding for the SEC. Much of Congress's early 1990s funding cutbacks arose out of the anti-regulatory thinking then dominating Congress. One aspect is telling: Some in Congress wanted to give the SEC authority to levy higher user fees, which the SEC could then use for its own operating budget. But, said Senator Phil Gramm and his allies, if the SEC could self-finance via user fees it would

\footnotetext{
32 John Cassidy, "The Greed Cycle: How the financial system encouraged corporations to go crazy,” The New Yorker, September 23, 2002, 64, 69. And FASB is a self-regulatory operation, not an independent imposing regulator. William W. Bratton, "Rules, Principles, and the Accounting Crisis in the United States,” European Business Organization Law Review 5 (2004): 7-25.

${ }^{33}$ At p. ...

${ }^{34}$ Jess Eisinger, “Microsoft Can Count. Intel Can’t,” Wall Street Journal, July 21, 2004.
} 
become more independent from Congress. ${ }^{35}$ Gramm won. So the chain persisted: interest groups-like our gatekeepers-can influence Congress, and Congress can control the SEC.

After Enron broke, there was a flurry of reform thinking, but it faded quickly from the congressional agenda, apparently with managerial blessing and lobbying, ${ }^{36}$ and didn't seem likely to produce action until WorldCom collapsed. With WorldCom's collapse, members of Congress who had opposed strong regulatory reform changed their minds.

(d) Today: Lobbying the SEC on shareholder access. In the wake of Enron, the SEC concluded that America's boards - the primary gatekeeper of internal managerswould be stronger if stockholders of poorly performing companies could get access to the company's proxy statement to elect a couple of directors. Nothing dramatic, but a tilt toward opening up the boardroom. (The usual American practice is that incumbent managers get their nomination and reelection expenses paid for by the company itself; others nominating directors have to pay their own expenses, which typically amount to millions of dollars.) British shareholders may remove directors, nearly at will. The SEC proposal would stop far short of that.

But thus far managers have stymied the SEC, pressuring it to back off "in the face of opposition from the Chamber of Commerce and the Business Roundtable, an organization of chief executives from the nation's largest companies."37 The SEC's retreat was seen as a "major victory for corporate executives who have fought to kill the rule."38 Managers had beaten back shareholder access proposals over the decades, ${ }^{39}$ and thus far seem to have done so again, pushing the SEC back to a weakened version of its original plan. ${ }^{40}$ The regulated beat back reform that would have narrowed that gap in the separation of ownership from control, our fundamental fissure. They used information (arguing that the rule wouldn't work well, would disrupt boardrooms, and would be used primarily by special interests) and worst-case scenarios (paralyzed boards or boards dominated by special interests without a shareholder agenda or, worse, with an anti-shareholder agenda ${ }^{41}$ ), and tapped the Congress and the White House as levers. ${ }^{42}$

35 “S.E.C. Budget Request Cut,” New York Times, June 28, 1994; Rovella, “Congressional Ploys Squeeze SEC Budget; A fight over the agency’s budget creates fiscal crisis”.

${ }^{36}$ William Neikirk, “Andersen: The Fallout,” Chicago Tribune, June 18, 2002 (corporate lobbying to stall reform).

${ }^{37}$ Stephen Labaton, “S.E.C. at Odds on Plan to Let Big Investors Pick Directors,” New York Times, July 1, 2004. See also Adrian Michaels, "Vote on Reforming Boardroom Elections Delayed by SEC Split,” Financial Times, June 1, 2004; Deborah Solomon, "SEC May Temper Plan to Boost Shareholders’ Powers,” Wall Street Journal, April 19, 2004.

${ }^{38}$ Labaton, "S.E.C. at Odds on Plan to Let Big Investors Pick Directors."

${ }^{39}$ Mortimer M. Caplin, "Proxies, Annual Meetings and Corporate Democracy: The Lawyers' Role,” Virginia Law Review 37 (1951): 653, 682-684.

40 Deborah Solomon, “SEC Nears Compromise on Shareholder Plan,” Wall Street Journal, August 11, 2004.

${ }^{41}$ Presumably they are referring to funds described in Damon Silvers' essay in this volume, at p. _. When the SEC in 1992 cut back rules that had made it a potentially criminal offense for investors to talk with one another about a bad board, some managerial groups were similarly unhappy with the potential of more gatekeeper oversight. "Big-business leaders blasted the proxy change, 


\section{CONCLUSION}

American corporate governance has two inevitable instabilities. With control separated from ownership, managers' agenda differs from that of others inside the corporation; and, especially with ownership fragmented, a few managers sometimes go bad, demeaning their corporations and, if the misconduct is widespread enough, even the economy. Technology changes, crises arise, and the problems in one decade differ from those of another decade. But the principal problems arise from ownership separation, and ownership separation is with us to stay.

Other nations have less ownership separation but that comes with another set of problems, mostly those that arise from concentrated ownership (via insider machinations) and weak stock markets (because one key financing source is less viable). To say that our problems derive from separation isn't to say that we can do better by giving up separation. It just says that we have to deal repeatedly with separation's derivative problems.

Thus we fix up each current problem, and we muddle through. ${ }^{43}$ We'll further professionalize directors, as called for in the essay in this volume by Martin Lipton and Jay W. Lorsch. ${ }^{44}$ But comprehensive, once-and-for-all "solutions" to the enduring challenges of American corporate governance are implausible. So we go for ad hoc and partial solutions, like more professionalization and some of the Sarbanes-Oxley regulation, and then we move on.

The essays that follow properly look at the breakdowns in gatekeepers that led to Enron and the associated scandals, and the Recommendations for Practice suggest how we can improve gatekeeper performance. ${ }^{45}$ The gatekeepers are there because

contending that it will allow well-heeled shareholders to plot against the interests of companies and smaller holders without notification. It is 'hard to fathom why the commission would allow big, powerful investors the right to line up votes for a proxy contest . . . without some kind of public disclosure to the other shareholders,' said . . . an official of the Business Roundtable[.]" Kevin Salwen, "SEC Votes to Ease Barriers to Holders' Communications," Wall Street Journal, October 16, 1992.

42 Adrian Michaels, “Board Election Rules Debate Defies Unanimity,” Financial Times, June 16, 2004: "The SEC has entered ... mainstream politics. The issue of proxy access involves pressure from the White House. The Business Roundtable is crucial to [the Bush administration's] fundraising." The quotation was of John Coffee, professor of law at Columbia Law School. Cf. Adrian Michaels, "Vote on reforming boardroom elections delayed by SEC split," Financial Times, June 1, 2004 (the shareholder access proposals "have pitted powerful business lobbyists against activist institutional investors”). “Opponents of the proposals, such as the Business Roundtable, the powerful chief executive grouping, and the US Chamber of Commerce, say the plans would cause significant disruption even at well-run companies.” Id.

${ }^{43}$ Cf. Charles E. Lindblom, “The Science of 'Muddling Through,”' Public Administration Review 19 (1959): 79-88.

${ }^{44}$ At p. _ _ and p. _ , respectively. See also Margaret Blair's essay on p. __. John S. Reed's essay also calls for professionalization, although not with that vocabulary. Richard W. Painter, at p. — is skeptical as to whether self-regulatory "clubs"-he focuses primarily on lawyers — can be effective without good regulation. Those ideas might extend to wondering whether professionalization of directors, alone, without good supporting regulation will work effectively.

${ }^{45}$ Consider also the essays by William R. Kinney, at p. _ , and John H. Biggs, at p. _ (both on accountants); William T. Allen and Geoffrey Miller, at p. __ (on lawyers); and Felix G. Rohatyn, at p. _ , and Gerald Rosenfeld, at p. _ (both on investment bankers). 
managers and boards need to be checked. It's the board and managerial breakdown in the Enron, WorldCom, and the other big scandals that was primary. The gatekeepers were backstops.

And the first instability interacts with the second one. American corporate governance is porous. We have multiple regulators, each with strengths and weaknesses. Moreover, the regulated often affect how they're regulated. Some of the breakdowns in the gatekeepers, and in the efforts to shore them up, emanated from the actions of the core group to be controlled-often American managers themselves, sometimes accountants, sometimes promoters of Silicon Valley start-ups. The regulated often sought to weaken the regulation that would have reduced their-the managers'-discretion. Shareholders-diffuse and distant-have thus far been less well organized both in affecting firms and in affecting regulators and regulations, although that may change. Some of this weakness in regulation and the regulators may well be good. It reduces rigidity. It facilitates change and entrepreneurial innovation. It gives us multiple informational channels into the regulators, so that the rules that emerge are more likely to be useful.

But not all porosity is good. Some of it has stopped government players from correcting breakdowns that derive from the separation of ownership from control, because the regulated often seek to deter not just bad regulation, but any regulation. Some of the gatekeeper breakdowns that the essays in this volume analyze might have been prevented had gatekeepers and managers not influenced regulators in ways that diminished the gatekeepers' effectiveness. The point here is not that centralization beats decentralization; centralization has its costs, and the regulatory difficulties in other countries display them. The point is that decentralization is our problem, not that there's a fundamental, once-and-for-all solution to the problem.

When Congress acts, in some odd ways it has reason to overreact in the very way that the regulated often fear: when it can act, because the issue is salient, public servants may think that porosity will allow the regulated in the future to beat back some of the rules. So public servants may actually seek more rigidity than is ideal, to reduce future erosion. Put the package together-the regulated as able to affect the regulators and weaken their output, and regulators who when able to act think they must lock it all in - and we've made for more brittleness in corporate governance regulation than would be ideal.

This won't be the last time that corporate governance breaks and cracks in a key way. Different stress points will develop in the public firm, and one or another of the persisting fissures will threaten to open, crack, and need to be fixed. If we're lucky, someone will anticipate the problem and fix it up beforehand. If not, we'll muddle through once again. It's worked so far. 